\title{
Analysis of Alternative Strategy in Coastal Tourism Development in Aceh Besar, Indonesia after Tsunami Disaster
}

\author{
Achmad Fadillah, Triana G. Dewi, and Arini Hardjanto
}

\begin{abstract}
There are many factors that influence the development of coastal tourism in Aceh Besar, Indonesia. To be able to provide solutions in developing coastal tourism is certainly necessary to know there are external and internal factors that can support or hinder the development of coastal tourism in Aceh Besar. From the description above, the aims of this research are: to analyze the external factors that influence the development of tourism in Aceh Besar, to analyze the internal factors that influence the development of tourism in Aceh Besar, and to analyze strategies and priority of strategies that may be proposed to develop coastal tourism in Aceh Besar. Data processing method based on the concept of Fred R. David is composed of the input stage, the matching stage, and the decision stage. Analysis tools use matrix of IFE, EFE, and SWOT to formulate and establish the strategy. After the research was carried out, it formulated ten alternative strategies. Based on QSP matrix, the strategy of the increasing government support for coastal development and management is the first order of priority to increase the development of coastal tourism in Aceh Besar.
\end{abstract}

Index Terms-Coastal tourism, alternative strategy, SWOT matrix, QSPM, aceh besar.

\section{INTRODUCTION}

\section{A. Background}

Tourism is one of industry that can improve a country's economic growth. This fact has been emphasized in some studies [1]-[2]. It is seen from the role that tourism can increase employment, incomes and standard of living and provide stimulus for the development of other sectors. Indonesia tourism sector proved to able to withstand the pressure of the global economy crisis. Through the Visit Indonesia Year 2009, the tourism sector managed to attract tourists and bring in as many as 6.5 million people with foreign exchange earnings at $\$ 7.5$ million in which the outcome was in line with the targets announced by the government [3].

Coastal tourism is one of potential tourism it will be able to be developed because Indonesian coastline is quite long which is about $95.181 \mathrm{~km}$, the fourth longest coastline in the world ${ }^{1}$. The similar study which has been carried out in Korea [4] concluded that coastal tourism become popular for travelling and increase the demand of tourists.

Manuscript received March 20, 2012; revised April 10, 2012

A. Fadillah and T. G. Dewi are with Master Science of Agribusiness, Bogor Agricultural University, Sponsored by Beasiswa Unggulan-BPKLN, Ministry of National Education, Indonesia (e-mail: achmad.fadillah@rocketmail.com; trianagita@gmail.com).

A. Hardjanto is with Master Science of Agricultural Economics, Bogor Agricultural University, Indonesia (e-mail: arini88hardjanto@gmail.com).

${ }^{1}$ wikipedia
Banda Aceh province is one of the provinces in Indonesia which has coastline about $2666.27^{2}$ so the Banda Aceh province has big potential of the coastal tourism. Due to soil conditions, tide and waves are different, not all coastal area can be a coastal tourism object. Aceh Besar is located at the tip of Banda Aceh province. It is a district with considerable coast tourist. Some coasts at Aceh Besar which are frequently visited by local tourists are Lampuuk, Ujung Batee and Lhoknga. Unfortunately, tsunami disaster in 2004 destroyed coastal tourism in that area. In order to be able to make tourists keep visiting to that area, Aceh Besar authority should carry out the policy to arrange the strategy to develop coastal tourism. The use of SWOT analysis in developing some strategies in tourism sector has been done by Subramoniam, Al-Essai, Al-Marshadi and Al-Kindi [5].

\section{B. Formulation of Problems and Objection}

Tsunami disaster in Banda Aceh Province that occurred in 2004 had given significant impacts on the condition of this province. One of the greatest damage is the beach area where it is the main source of income for most people in Aceh. The potential coastal tourism in Aceh Besar was laid down due to tsunami destruction. Nevertheless, tourism in Aceh Besar district still has high chances to be mainstay tourism which can attract visitors not only local visitors but also outside the region. Lampuuk, Ujung Batee, and Lhoknga are beaches where tourist attraction can be relied on. Despite having high opportunity to be potential coastal tourism, it will be stagnated if there is no significant contribution from the government

There are internal and external factors that influence the development of coastal tourism in the district of Aceh Besar. To provide solutions for developing coastal tourism is certainly necessary to know The external and internal factors that can support or hinder the development of coastal tourism in the district of Aceh Besar. From the description above, the aims of this research are:

1. To analyze the external factors that influence the development of tourism in Aceh Besar district.

2. To analyze the internal factors that influence the development of tourism in Aceh Besar district.

3. To analyze the strategies and priority of strategies that may be proposed to develop coastal tourism in Aceh Besar district.

\section{DAta AnAlysis MeTHOD}

Data processing method based on the concept of Fred R.

\footnotetext{
${ }^{2}$ http://rimanews.com/read/20110616/31977/kekayaan-pesisir-aceh-me njanjikan-tapi-kesejahteraan-masyarakat-menyedihkan
} 
David is composed of the input stage, the matching stage, and the decision stage. Analysis tools use a matrix of IFE, EFE, SWOT, and QSP to formulate and establish the strategy. Here is an overview stages in the formulation of strategy can be seen in Fig. 1.

\begin{tabular}{c}
\begin{tabular}{c|} 
Stage 1: (The Input Stage) \\
IFE (Internal Factor Evaluation) Matrix \\
EFE (External Factor Evaluation) Matrix
\end{tabular} \\
$\frac{\text { Stage 2: (The Matching Stage) }}{\text { SWOT Matrix }}$ \\
(Strengths, Weaknesses, Opportunities, dan Threats) \\
QSPM (Quantitative Strategic Planning Matrix) \\
\hline
\end{tabular}

Fig.1. Prime strategy determining stage

Source: David (2004), refers to [6]

Input stage is used to summarize basic information which is needed to formulate strategy with use IFE matrix (Internal Factor Evaluation) and EFE Matrix (External Factor Evaluation). These basic information are got by primary and secondary data. Matching stage formulates strategies, this second stage use SWOT matrix. The third stage continued the stages of decision-making using QSPM.

\section{A. The Input Stage}

IFE matrix is used to identify the internal factors and measure the strengths and weaknesses which had by an area, whereas the EFE matrix is used to identify external environmental factors and measure the opportunities and threats which had by an area. After classifying the factors into the strengths, weaknesses, opportunities and threats, the factors have to be weightened.

Weighting will be done by submitting the identification of internal and external strategic factors to the respondent by using the "paired comparasion". This method is used to provide an assessment of the weight of each internal factor. Each variable used a scale of 1,2 , and 3 to determine the weights. Scale used to determine the weights are:

$1=$ If the indicator is less important than horizontal vertical indicator.

$2=$ If the indicator is as important as horizontal rather than vertical indicator.

$3=$ If the indicator is more important than horizontal vertical indicator.

Forms of assessment weighting is shown in Table I. How to read the comparison starts from the variable line (vertical indicator) compared to the column variable (horizontal indicators) and must be consistent.

TABLE I: WEIGHT FACTORS FOR STRATEGIC ASSESSMENT

\begin{tabular}{|c|l|l|l|l|l|l|}
\hline \hline $\begin{array}{c}\text { Strategies } \\
\text { Factors }\end{array}$ & $\mathrm{A}$ & $\mathrm{B}$ & $\mathrm{C}$ & $\mathrm{D}$ & $\ldots \ldots$ & Total \\
\hline $\mathrm{A}$ & & & & & & $\mathrm{X}_{\mathrm{i}}$ \\
\hline $\mathrm{B}$ & & & & & & \\
\hline $\mathrm{C}$ & & & & & & \\
\hline$\ldots .$. & & & & & & \\
\hline Total & & & & & & $N$ \\
\hline
\end{tabular}

Source: David (2011)

Weight of each variable is obtained to determine the value of each variable to the overall value of the variable number by using the formula:

$\alpha 1=\frac{x t}{\sum_{i=1}^{n} x_{t}}$

where;

$\alpha \mathrm{i}=$ Weight of the $\mathrm{i}$-th variable $\quad \mathrm{n}=$ Number of data $X \mathrm{i}=$ value of variable $\mathrm{x}$ to- $\mathrm{i}$$$
\mathrm{i}=1,2,3, \ldots, \mathrm{n}
$$

The weight given to each factor indicates the degree of relative importance of factors to the success of the industry's top companies. Without looking at the key factor is the internal strength or weakness, or opportunity or external threat, factors that are considered to have great influence in the company's performance should be given the highest weighting. The sum of all weights must be equal to 1.0.

After weighting stage, the next step is to determine the rating. Rating determination by respondents who have an interest in the excavations carried out on primary data variables. The measure of each variable on the condition of the area use a scale of 1, 2, 3, and 4 for each strategic factor. IFE matrix and EFE matrix is shown in Table II and Table III.

According to [7] scale rating for the IFE matrix (strengths and weaknesses) are:

$$
\begin{aligned}
& 1=\text { major weakness } \\
& 2=\text { minor weakness } \\
& 3=\text { minor strength } \\
& 4=\text { major strength }
\end{aligned}
$$

As for the EFE matrix (opportunities and threats), the rating scale used was:

$$
\begin{aligned}
& 1=\text { Below average response } \\
& 2=\text { Average response } \\
& 3=\text { Above average response } \\
& 4=\text { Very good response }
\end{aligned}
$$

Rating determination made by each respondent, then be incorporated into the composite matrix IFE and EFE. For the rating on the acquisition value of the combined matrix is done using the average method.

TABLE II: INTERNAL FACTOR EVALUATION (IFE) MATRIX

\begin{tabular}{|l|c|l|l|}
\hline \hline \multicolumn{1}{|c|}{ Main Internal Factors } & Weight & Rating & Weight Score \\
\hline Strength & & & \\
$1 \ldots .$. & & & \\
$2 \ldots .$. & & & \\
Weakness & & & \\
$1 \ldots .$. & & & \\
$2 \ldots .$. & 1,00 & & \\
\hline \multicolumn{1}{|c|}{ Total } & & \\
\hline \hline
\end{tabular}

Source: David (2011)

TABLE III: EXTERnAl FACTOR EVALUATION (EFE) MATRIX

\begin{tabular}{|l|c|c|c|}
\hline \multicolumn{1}{|c|}{ Main External Factors } & Weight & Rating & Weight Score \\
\hline Opportunities & & & \\
$1 \ldots . .$. & & & \\
$2 \ldots .$. & & & \\
Threat & & & \\
$1 \ldots .$. & & & \\
$2 \ldots .$. & 1,00 & & \\
\hline \multicolumn{2}{|c|}{ Total } & & \\
\hline \hline
\end{tabular}

Source : David (2011)

Total weighting score IFE will range from 1 to 4 with an average of 2.5. If the total score weighting IFE 3.0 to 4.0 means the internal conditions of region is high and strong, then if the 2.0 to 2.99 means that the internal conditions of region is medium, and from 1.0 to 1,99 means that the internal conditions of region is low or weak.

Total weighting score EFE will range from 1 to 4 with an 
average of 2.5. If the total score weighting EFE 3.0 to 4.0 means the strong response to the opportunities and threats affecting the area, then if the 2.0 to 2.99 means that regions are responding to the opportunities and threats, and from 1.0 to 1,99 means the regions can not respond to the opportunities and threats.

\section{B. The Matching Stage}

The second stage is the matching stage of data by using the SWOT matrix. SWOT matrix use to obtain an alternative strategy based on internal and external factors such as strengths, weaknesses, opportunities and threats. Benefits of SWOT analysis are simple, multipurpose, and can be used to plan the future [8]. SWOT matrix matching is an important tool to help governments and other stakeholders to develop four types of strategies, which include: 1) strategies SO (strength-opportunity) is a strategy that uses the internal strength to take advantage of external opportunities, 2) WO strategy (weakness-opportunity) is a strategy aimed at improving internal weaknesses with external opportunities, 3) ST strategy (strength-threat) that is a strategy that uses an internal power to prevent or reduce the influence of external threats, 4) strategy WT (weakness-threat) is a strategy that directed at reducing internal weaknesses and avoiding external threats.

TABLE IV: SWOT MATRIX

\begin{tabular}{|c|c|c|}
\hline & \begin{tabular}{l}
\multicolumn{2}{l}{ Strenghts(S): } \\
$1 . \quad \ldots \ldots$ \\
2. \\
\end{tabular} & $\begin{array}{l}\text { Weaknesses }(\mathrm{W}): \\
1 . \quad \ldots \ldots \\
2 . \quad \ldots \ldots \\
\end{array}$ \\
\hline $\begin{array}{l}\text { Opportunities } \\
\text { (O): } \\
1 . \\
2 . \quad \ldots \ldots \\
2 .\end{array}$ & $\begin{array}{l}\text { Strategi SO } \\
\text { Use the strengths to } \\
\text { utilize the opportunities }\end{array}$ & $\begin{array}{l}\frac{\text { Strategi WO }}{\text { Overcome the weaknesses }} \\
\text { with utilize the opportunity }\end{array}$ \\
\hline $\begin{array}{l}\text { Threats }(\mathrm{T}): \\
1 . \quad \quad \ldots \ldots \\
2 . \quad \quad \ldots . .\end{array}$ & $\begin{array}{l}\text { Strategi ST } \\
\text { Use the strengths to } \\
\text { avoid the threats }\end{array}$ & $\begin{array}{l}\text { Strategi WT } \\
\text { Minimize the weaknesses } \\
\text { and avoid the threats }\end{array}$ \\
\hline
\end{tabular}

Source: David (2011)

\section{The Decision Stage}

The last stage to determine the best strategic priorities that will be executed is the decision stage. One of the tools of analysis at this stage is the Quantitative Strategic Planning Matrix (QSPM). According to [7], QSPM is a tool that allows strategists to evaluate alternative strategies objectively, based on critical success factors of external and internal, have been identified previously. According to [7], there are six steps required to develop the QSPM, which is:

1. Make a list of the various opportunities and external threats and internal strengths and weaknesses in the left column QSPM. This information should be taken directly from the EFE and IFE matrix.

2. Giving weight to each of the major internal and external factors.

3. Looking at the matrix-matrix stage 2 (matching) and then identifies various strategic alternatives.

4. Determine Attractiveness Score-AS. AS is a numeric value that indicates the relative of strategic alternatives. Score range is $1=$ no have attraction, $2=$ low attraction, $3=$ medium attraction, $4=$ high attraction.

5. Calculate the total Attractiveness Score-TAS. TAS is a product of the weight of the score in each row.

6. Calculate the total amount of the overall by summing the total score in each column of QSPM strategy. The total number of TAS suggests strategies that run priority of all strategic alternatives.

TABLE V: QSP (QuANTITATIVE STRATEgIC PlanNing) MAtrix

\begin{tabular}{|l|l|l|l|l|l|l|l|}
\hline \hline \multirow{2}{*}{ Main Factors } & \multirow{2}{*}{ Weight } & \multicolumn{6}{|c|}{ Strategic Alternatives } \\
\hline & & Strategy 1 & Strategy 2 & \multicolumn{2}{|c|}{ Strategy 3 } \\
\hline & & AS & TAS & AS & TAS & AS & TAS \\
\hline $\begin{array}{l}\text { Opportunities } \\
\text {..... }\end{array}$ & & & & & & & \\
\hline $\begin{array}{l}\text { Threats: } \\
\ldots . .\end{array}$ & & & & & & & \\
\hline $\begin{array}{l}\text { Strenghts: } \\
\ldots . .\end{array}$ & & & & & & & \\
\hline $\begin{array}{l}\text { Weaknesses: } \\
\ldots . .\end{array}$ & & & & & & & \\
\hline \multicolumn{1}{|c|}{ Total } & & & & & & & \\
\hline \hline
\end{tabular}

Source : David (2011)

\section{RESUlt AND ANALysis}

A. Identification and Analysis Internal-External Factors of Coastal Tourism Development Strategy in Aceh Besar

1) Internal Factors

- Strengths

a. Strategic location

The location of the beach in Aceh Besar district is very strategic because it is taken only 25-30 minutes by car.

b. Having natural beauty

The beauty of the beach is very natural with white sand and big wave. This beach is suitable for water sport and surfing.

c. Affordable entrance ticket

The ticket to enter the beautiful beach is only about 5000 rupiah $^{3}$.

d. Hospitality

The hospitality of the local people are very high. They always welcome to the tourists.

e. Government tourism programs of Aceh Besar Government tourism programs of Aceh Besar is trying to develop many potential tourism sectors, such as natural and crafts tourism. The local government of Aceh Besar also has been developing and promoting new tourism types, namely, spiritual and family tourism.

- Weaknesses

a. The lack of government supports

There are not enough media and information about coastal tourism. The government should have provided brochures, booklets, leaflets, postcards, banners, $\mathrm{CD}$ and joining tourism exhibition.

b. The inadequate of fund

Tourism sector budget is relatively small in district of Aceh Besar, so there are many obstacles to develop the coastal tourism.

c. Less in infrastructure development

Inadequate development of infrastructure such as roads and other public facilities are also barrier that must be established immediately.

d. The illegally of tourism facility

${ }^{3}$ http://serambinews.net/news/view/40279/menyoal-omset-pantai-lamp uuk 
Many stores or shops are illegally built around the coast because local government is not serious in caring and maintaining coastal tourism facilities.

e. The absence of a legal entity for coastal management Beaches should be managed by local governments, but in real most beaches is independently managed by local community.

f. The absence of good management in coastal tourismt Local government is not serious in developing coastal tourism. It can be seen by noot good maintenance of caostal area.

\begin{tabular}{|c|c|c|c|}
\hline Main Internal Factors & Weight & Rating & $\begin{array}{l}\text { Weight } \\
\text { Score }\end{array}$ \\
\hline \multicolumn{4}{|l|}{ Strengths } \\
\hline Strategic location & 0,087 & 3,25 & 0,283 \\
\hline Having natural beauty & 0,089 & 3,25 & 0,289 \\
\hline Affordable entrance ticket & 0,096 & 3,25 & 0,312 \\
\hline Hospitality & 0,091 & 3,5 & 0,319 \\
\hline $\begin{array}{l}\text { Government tourism programs of } \\
\text { Aceh Besar }\end{array}$ & 0,079 & 3,75 & 0,296 \\
\hline \multicolumn{4}{|l|}{ Weaknesses } \\
\hline The lack of government supports & 0,092 & 1,5 & 0,138 \\
\hline The inadequate of fund & 0,090 & 2 & 0,180 \\
\hline $\begin{array}{l}\text { Less in infrastructure } \\
\text { development }\end{array}$ & 0,092 & 2,25 & 0,207 \\
\hline The illegally of tourism facility & 0,098 & 2 & 0,196 \\
\hline $\begin{array}{l}\text { The absence of a legal entity for } \\
\text { coastal management }\end{array}$ & 0,089 & 2 & 0,178 \\
\hline $\begin{array}{l}\text { The absence of good management } \\
\text { in coastal tourismt }\end{array}$ & 0,098 & 1,75 & 0,172 \\
\hline Total & 1,000 & & 2,569 \\
\hline
\end{tabular}

Source: Primary data, processed

Total weighting score IFE 2,569 means that the internal conditions of region is medium condition to use and handle.

\section{2) External Factors}

- Opportunities

a. The support of Banda Aceh province for developing tourism sector in Aceh Besar

Banda Aceh province has launched a program called Visit banda Aceh Year 2011. The aims of this program is to make Banda Aceh as a leading tourism destination in Indonesia.

b. Tourism now becomes necessity for Indonesian people

Nowadays tourism is not a luxurious activity anymore, but it has evolved into a necessity for most people due to fatigue from work.

c. Local government regulations that support tourism activity

Aceh Qanun Number 5 Year 2007 regarding Organization and Working Procedure of the Office, the Regional Technical Institute and Institute of Aceh Province has established a Department of Culture and Tourism of Aceh with the duties and functions of the main establishing and developing of Culture and Tourism sector in everyday life. While the design of Aceh Qanun on tourism is one of the Aceh government's priority in $2012^{4}$.

d. The increasing of Indonesian people's interest to coastal tourism

${ }^{4}$ http://acehtourismagency.com/index.php?op=view_artikel\&id=16\&da $\mathrm{ftar}=$ menu
Coastal tourism now become one of the most favourite tourist destination in Indonesia.

e. A willingness to invest and provide assistance for the development of post-tsunami Aceh

The amount of assistance from domestic and foreign countries to restore life in Aceh after the tsunami have positive impact on tourism sector. Aceh's natural beauty can attract foreign tourists to invest.

f. The increasing number of tourist in Banda Aceh During the process of rehabilitation and reconstruction, Aceh has had experienced significance progress, including the increasing number of tourist visits, the number of restaurant and hotel as well as an increase in hotel occupancy rates. Tourism facilities in Banda Aceh has developed. It has to 20 star hotels, 25 homestay and small hotels with a total of 1910 rooms which has capacity about 3820 people and 414 table restaurant with total capacity about 14227 people $^{5}$.

- Threats

a. The insecurity and political situation in Aceh Besar The uncertainty of political and insecurity situation can be a threat for coastal tourism in the district of Aceh Besar. Conducive of political and security situation is a must in order to increase the demand for tourism.

b. The unpredictable natural change

Natural factors play an important role in tourism. Banda Aceh natural conditions are fragile for earthquakes with tsunami potential.

c. Various tourist destination

The are variety of tourism offered by other district in Banda Aceh and provinces in Indonesia. Important to analyze all the competitors [9].

d. Miscultivating of coastal area

Indonesia is a developing country which has relatively high levels of poverty. Many people work under existing natural resources and even damage it. Coastalland is not only used for tourism object, but also for cultivating salt.

e. Lack of socialization of local law

In 2006 the province of Banda Aceh was granted a special privilage to execute Islamic law in every aspect of life including tourism sector, but because it is new, so the law has not been carried out thoroughly.

Total weighting score EFE 2,699 means that regions are responding to the opportunities and threats.

\section{B. Synthesis of Alternative Solutions in Coastal Tourism Development Strategy in Aceh Besar (SWOT Matrix)}

These factors include internal forces (strengths) and (weaknesses), as well as external forces (opportunities) and (threats) that can be synthesized to generate alternative strategies. These strategies include:

1) Strength-Opportunity Strategies (S-O)

These strategies are synthesized through utilization of strengths and take advantage of available opportunities. The proposed strategies are:

- Strategy 1: The increasing government support for coastal development and management tourism (S1, $\mathrm{O} 2, \mathrm{O} 4, \mathrm{O} 6$ )

\footnotetext{
${ }^{5} \mathrm{http}$ //acehtourismagency.com/index.php?op=view_artikel\&id=6\&daf
} tar=_menu 
TABLE VII: EFE MATRIX

\begin{tabular}{|c|c|c|c|}
\hline Main External Factors & Weight & Rating & $\begin{array}{l}\text { Weight } \\
\text { Score }\end{array}$ \\
\hline \multicolumn{4}{|l|}{ Opportunities } \\
\hline $\begin{array}{l}\text { The support of Banda Aceh province for } \\
\text { developing tourism sector in Aceh Besar }\end{array}$ & 0,086 & 2,5 & 0,215 \\
\hline $\begin{array}{l}\text { Tourism now becomes necessity for } \\
\text { Indonesian people }\end{array}$ & 0,100 & 3 & 0,300 \\
\hline $\begin{array}{l}\text { Local government regulations that support } \\
\text { tourism activity }\end{array}$ & 0,086 & 2,25 & 0,194 \\
\hline $\begin{array}{l}\text { The increasing of Indonesian people's } \\
\text { interest to coastal tourism }\end{array}$ & 0,099 & 3 & 0,297 \\
\hline $\begin{array}{l}\text { A willingness to invest and provide } \\
\text { assistance for the development of } \\
\text { post-tsunami Aceh }\end{array}$ & 0,094 & 3,25 & 0,306 \\
\hline $\begin{array}{l}\text { The increasing number of tourist in Banda } \\
\text { Aceh }\end{array}$ & 0,097 & 3 & 0,291 \\
\hline Main External Factors & Weight & Rating & $\begin{array}{l}\text { Weight } \\
\text { Score }\end{array}$ \\
\hline \multicolumn{4}{|l|}{ Threats } \\
\hline $\begin{array}{l}\text { The insecurity and political situation in } \\
\text { Aceh Besar }\end{array}$ & 0,099 & 2,75 & 0,272 \\
\hline The unpredictable natural change & 0,084 & 2 & 0,168 \\
\hline Various tourist destination & 0,083 & 2,25 & 0,187 \\
\hline Miscultvating of coastal area & 0,085 & 2,75 & 0,234 \\
\hline Lack of socialization of local law & 0,086 & 2,75 & 0,237 \\
\hline Total & 1,000 & & 2,699 \\
\hline
\end{tabular}

Source: Primary data, processed

Indonesian people love to travel to tourism object and make it as basic necessity. The growing interest of Indonesia people for coastal tourism, increased the number of visits to coasts in Aceh. Aceh Besar is one of the tourism destination for the local community, because of strategic location and natural beauty made. Government can influence some main factors of competitiveness regions positively [10].

However this tourism object should be supported by better coastal development and management; such as development of infrastructures (resorts, restaurants, rides, roads, parking lots, business stalls, etc.) in oredr to increase the potential added value of the beach.

- Strategy 2: Empowering local communities to actively participate in the development of coastal tourism (S4, O6)

The increase of tourism visits in Aceh can be further improved through the utilization of culture of local people around the beach -such as warm-hearted - especially on the Aceh Besar coast. One of the way is by empowering of local communities tourism object through providing employment opportunities for people. Therefore the local communities gain benefit from the development of tourism in Aceh Besar. 2) Strength-Threat Strategies (S-T)

These are proposed strategies with the use of strength to avoid the threat. The proposed strategies are:

- Strategy 3: Keep the entrance ticket cheap and provide good service, to compete with other alternative tourism destination (S3, T3)

The number of tourist visits to tourism object is affected by costs. Cheap entrance ticket on the coast of Aceh Besar is one of the attractive factor, so that visitors will not turn to other tourism alternatives. The local government should keep the entrance ticket cheap and followed by good service.

- Strategy 4: Hold a festival / event in the coastal resorts to attract tourist (S5, T3)

The existance of tourism alternatives other than coastal marine tourism are threats for the development of tourism in Aceh Besar. The introduction of tourism object in Aceh Besar should be enforced through government programs in tourism. One of the program is to hold a festival/ event in coastal resorts.

- Strategy 5: The local law must be socialized to the local people and tourists as well to make tourists feel secure (S5, T5)

Aceh local customary law should be maintained, but the lack of socialization of the law to the people outside the area may reduce the comfort and security of the people and tourists. Hence it need to be disseminated by the government through some tourism programs in Aceh Besar.

\section{3) Strategic Weakness-Opportunity (W-O)}

This strategy is synthesized to reduce the weaknesses with the use opportunities. The proposed strategies include:

- Strategy 6: Provide media information and promotion such as websites, media mass, etc. (W1, O2, O4, O6)

Indonesian people love to travel to tourism object and make it as basic necessity, increasing in interest of Indonesian people to Coastal tourism, the development of visiting tourist to Aceh Besar show that the market for tourism in Aceh Besar was growing fast, but have not widely known by many people. This is caused by a lack of media promotion and information. Therefore, in order to be better known, the government must provide media information and promotion such as websites, media mass, etc.

- Strategy 7: Increasing budget allocations for the development of tourism sector, especially coastal tourism (W2, O1)

The development of tourism in Aceh Besar has constrained by the limited of capital sources from government development Aceh Besar. Thus It needs increasing budget allocations for the development of the tourism sector especially coastal tourism. This can be achieved by using of local government support for developing tourist areas in Aceh Besar District, Aceh Province, and Indonesia.

- Strategy 8: Attracting Investors to invest in developing tourist areas by improving infrastructure (W2, W3, W4, O5)

Willingness to invest and provide assistance for the development of Aceh after the tsunami is an opportunity that can be used to cover up some weaknesses such as the limited of capital sources from government development Aceh Besar, the lack of road construction and parking area on the coast, non coordinated and illegally shop / store / restaurant on the coast of Aceh Besar. In order to develop the coastal tourism, local government need to attract investors to invest in developing tourist areas by improving infrastructure.

- Strategy 9: Collecting data and registering business units in coastal tourism (W4, O3)

The strategy is based non coordinated and permitted shop / store / restaurant on the coast of Aceh Besar. On the other hand, there are regulations of local governments and related agencies to support tourism. By collecting and registering data of business units on the coast of Aceh Besar, It is expected that business units have increasingly coordinated.

4) Strategic Weakness-Threat (W-T)

This strategy is synthesized on the basis of minimizing weaknesses to avoid threats. The proposed strategy are:

- Strategy 10: Making a coastal professional management strategy so that tourists feel comfortable 
and secure from crime and natural disasters (W5, W6, $\mathrm{T} 1, \mathrm{~T} 2, \mathrm{~T} 4)$

This strategy is done because there is no corporation and management that maintains the coastal tourism well. This strategy also is used to maintan secure situation in Aceh Besar, the uncertainty of natural condition change and use of coastal land in addition to tours. So that tourists can enjoy a comfortable coastal tourism.

TABLE VIII: SWOT MATRIX

\begin{tabular}{|c|c|c|}
\hline & Opportunities (O) & Threats (T) \\
\hline $\begin{array}{l}\text { Strengths } \\
\text { (S) }\end{array}$ & $\begin{array}{l}\text { S-O Strategies } \\
\text { - The increasing } \\
\text { government support for } \\
\text { coastal development } \\
\text { and management } \\
\text { tourism }(\mathrm{S} 1, \mathrm{O} 2, \mathrm{O} 4, \\
\text { O6) } \\
\text { - Empowering local } \\
\text { communities to actively } \\
\text { participate in the } \\
\text { development of coastal } \\
\text { tourism (S4, O6) }\end{array}$ & $\begin{array}{l}\text { S-T Strategies } \\
\text { - Keep the entrance ticket } \\
\text { cheap and provide good } \\
\text { service, to compete with } \\
\text { other alternative tourism } \\
\text { destination (S3, T3) } \\
\text { - Hold a festival / event in } \\
\text { the coastal resorts to } \\
\text { attract tourist (S5, T3) } \\
\text { - The local law must be } \\
\text { socialized to the local } \\
\text { people and tourists as well } \\
\text { to make tourists feel } \\
\text { secure (S5, T5) }\end{array}$ \\
\hline $\begin{array}{c}\text { Weaknesses } \\
\text { (W) }\end{array}$ & $\begin{array}{l}\text { W-O Strategies } \\
\text { - Provide media } \\
\text { information and } \\
\text { promotion such as } \\
\text { websites, media mass, } \\
\text { etc. (W1, O2, O4, O6) } \\
\text { - Increasing budget } \\
\text { allocations for the } \\
\text { development of tourism } \\
\text { sector, especially } \\
\text { coastal tourism (W2, } \\
\text { O1) } \\
\text { - Attracting Investors to } \\
\text { invest in developing } \\
\text { tourist areas by } \\
\text { improving infrastructure } \\
\text { (W2, W3, W4, O5) } \\
\text { Collecting data and } \\
\text { registering business } \\
\text { units in coastal tourism } \\
\text { (W4, O3) }\end{array}$ & $\begin{array}{l}\text { W-T Strategies } \\
\text { - Making a coastal } \\
\text { professional management } \\
\text { strategy so that tourists } \\
\text { feel comfortable and } \\
\text { secure from crime and } \\
\text { natural disasters (W5, W6, } \\
\mathrm{T} 1, \mathrm{~T} 2, \mathrm{~T} 4)\end{array}$ \\
\hline
\end{tabular}

\section{Priority of Strategies in Coastal Tourism Development in Aceh Besar}

The result of the value of Total Attractiveness Score (TAS) are ranked by its value. TAS sequence describes the priority order of strategies that can be implemented. The strategy with the highest TAS value is the most priority to be implemented to develop the coastal tourism in Aceh Besar. The order of priority based on the strategy of QSPM matrix shown in the following Table IX.

\section{CONCLUSION}

There are ten alternative strategies in coastal tourism development in Aceh Besar, Indonesia after tsunami disaster. Those are: (1) The increasing government support for coastal development and management tourism; (2) Empowering local communities to actively participate in the development of coastal tourism; (3) Keep the entrance ticket cheap and provide good service, to compete with other alternative tourism destination; (4) Hold a festival / event in the coastal resorts to attract tourist; (5) Socialization of local custom by written and verbal communication for the comfort and security of the people and the tourists;

TABLE IX: RESULT OF QSPM ANALYSIS

\begin{tabular}{|c|c|c|}
\hline Strategies & TAS & $\begin{array}{l}\text { Order of } \\
\text { Priority }\end{array}$ \\
\hline Strategy 1 & \multirow[b]{2}{*}{5,107} & \multirow[b]{2}{*}{ I } \\
\hline $\begin{array}{c}\text { The increasing government support for coastal } \\
\text { development and management tourism }\end{array}$ & & \\
\hline Strategy 2 & \multirow[b]{2}{*}{4,720} & \multirow[b]{2}{*}{ II } \\
\hline $\begin{array}{c}\text { Empowering local communities to actively } \\
\text { participate in the development of coastal } \\
\text { tourism }\end{array}$ & & \\
\hline Strategy 3 & \multirow[b]{2}{*}{4,144} & \multirow[b]{2}{*}{ VIII } \\
\hline $\begin{array}{l}\text { Keep the entrance ticket cheap and provide } \\
\text { good service, to compete with other } \\
\text { alternative tourism destination }\end{array}$ & & \\
\hline Strategy 4 & \multirow[b]{2}{*}{4,468} & \multirow[b]{2}{*}{ III } \\
\hline $\begin{array}{c}\text { Hold a festival / event in the coastal resorts to } \\
\text { attract tourist }\end{array}$ & & \\
\hline Strategy 5 & \multirow[b]{2}{*}{3,930} & \multirow[b]{2}{*}{$\mathrm{X}$} \\
\hline $\begin{array}{l}\text { The local law must be socialized to the local } \\
\text { people and tourists as well to make tourists } \\
\text { feel secure }\end{array}$ & & \\
\hline Strategy 6 & \multirow[b]{2}{*}{4,244} & \multirow[b]{2}{*}{ VII } \\
\hline $\begin{array}{l}\text { Provide media information and promotion } \\
\text { such as websites, media mass, etc }\end{array}$ & & \\
\hline Strategy 7 & \multirow[b]{2}{*}{4,424} & \multirow[b]{2}{*}{ IV } \\
\hline $\begin{array}{c}\text { Increasing budget allocations for the } \\
\text { development of tourism sector, especially } \\
\text { coastal tourism }\end{array}$ & & \\
\hline Strategy 8 & \multirow[b]{2}{*}{4,421} & \multirow[b]{2}{*}{$\mathrm{V}$} \\
\hline $\begin{array}{l}\text { Attracting Investors to invest in developing } \\
\text { tourist areas by improving infrastructure }\end{array}$ & & \\
\hline Strategy 9 & \multirow[b]{2}{*}{3,971} & \multirow[b]{2}{*}{ IX } \\
\hline $\begin{array}{c}\text { Collecting data and registering business units } \\
\text { in coastal tourism }\end{array}$ & & \\
\hline Strategy 10 & \multirow[b]{2}{*}{4,257} & \multirow[b]{2}{*}{ VI } \\
\hline $\begin{array}{l}\text { Making a coastal professional management } \\
\text { strategy so that tourists feel comfortable and } \\
\text { secure from crime and natural disasters }\end{array}$ & & \\
\hline
\end{tabular}

Source: Primary data, processed

(6) Collecting data and registering business units in coastal tourism; (7) Attracting Investors to invest in developing tourist areas by improving infrastructure; (8) Increasing budget allocations for the development of tourism sector, especially coastal tourism; (9) Provide media information and promotion such as websites, media mass, etc; (10) Making a coastal professional management system so that tourists feel comfortable and secure from crime and natural disasters.

Based on the analysis of alternative strategies QSPM formulated from the SWOT matrix shows the highest TAS value is Strategy 1 "Increasing Government Support For The Development and Management Coastal Tourism" with TAS value is 5.107. This strategy will be the first priority implemented to develop the coastal tourism in Aceh Besar after Tsunami disaster.

\section{REFERENCES}

[1] S. Malik, I. S. Chaudhry, M. R. Sheikh, and F. S. Farooqi, "Tourism, economic growth and current account deficit in Pakistan: Evidence from co-integration and causal analysis," European Journal of Economics, Finance and Administrative Sciences, Issue 22, 2010.

[2] G. B. Wickremasinghe and R. Ihalanayake, "The causal relationship between tourism and economic growth in Sri Lanka: Some empirical evidence," Working Paper Series School Of Applied Economics, December 2006.

[3] S. Maryam, "Pendekatan SWOT dalam pengembangan objek wisata kampoeng djowo sekatul kabupaten kendal," Undergraduate thesis, Economics Faculty, Diponegoro University, 2007. 
[4] S. G. Kim and Y. J. Edward Kim, "Overview of coastal and marine tourism in Korea", The Journal Of Tourism Studies, vol.7, no.2, December 1996.

[5] S. Subramoniam, S. A. N. Al Essai, A. A. M. Al-Marashadi, and A. M. A. Al-Kindi, "SWOT analysis on Oman tourism: A case study," in Journal of Economic Development, Management, IT, Finance and Marketing, 2(2), September, 2010, pp 1-22.

[6] H. Umar, Strategic Management in Action; Jakarta: PT Gramedia Pustaka Utama, 2008, ch 9, pp 219.

[7] F. R. David, Strategic Management: Concepts and Cases, 13rd ed; New Jersey: Prentice Hall, 2011, ch 6, pp 177-197.

[8] N. I. Soesilo, Manajemen Strategik di Sektor Publik, Depok: Magister Perencanaan dan Kebijakan Publik UI, 2002, ch 4, pp 4-4.

[9] M. E. Porter, Strategi Bersaing Teknik Menganalisis Industri dan Pesaing; Jakarta: Penerbit Erlangga, 1991, ch 3, pp 45.

[10] M. E. Porter, The Competitive Advantage of Nation; New York: The Free Press, 1990, ch 3, pp 127.

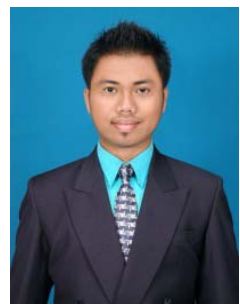

Achmad Fadillah was born in Bekasi, West Java, Indonesia on July, $17^{\text {th }} 1988$. Fadillah was graduated in 2011 from Bogor Agricultural University (IPB), Bogor, West Java, Indonesia majored in Agribusiness and minored in agricultural economics.In 2011 Fadillah continued his study in master degree Graduate School Bogor Agricultural University majored in Agribusiness Science.

He was an internship program at CV.Semesta Food, Jakarta, Indonesia in 2008. In 2009-2010 he was lecture assistant of basic sociology and basic economy in 2010-2011 at Bogor Agricultural University, Indonesia. In 2010 he was surveyor of Siatron Program at Ministry of Agriculture Indonesia. In 2011 he was surveyor of PT.PERTANI Program at Research Centre Bogor Agricultural Indonesia. He wrote some papers such as Minapolitan Based System Development Strategy Sustainability of Fisheries in the Framework for Economic Competitiveness Improvement \& Nation in 2010; Growth of the women Entrepreneurship Program Life and Sustainability-Based Business Earneing Guava in the Framework of Farm Women's Empowement Group (KWT) Sadeng Babakan Village, District Leuwisadeng, Bogor in 2010; Competitiveness Analysis of Fisheries Commodities in Sukabumi District.

Fadillah, BA joined some organizations in his college. He joined Students Executive Board Faculty of Economics \& Management FEM IPB (BEM FEM IPB) as a Head of Economics \& Entrepreneurship and also joined student club Century IPB as Vice President of Finance in 2007-2008. He joined Students Executive Board IPB (BEM IPB) as Staff of Human
Resource Development and Director of Leadership and Entrepreneurship School (LES) IPB in 2009-2010. He joined Students Executive Board IPB (BEM IPB) as Minister of Education Ministry in 2010-2011.

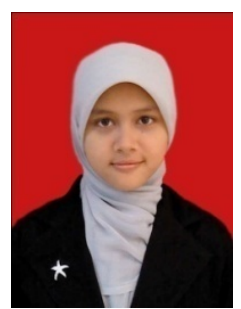

Triana Gita Dewi was born in Bandung, West Java, Indonesia on April, 20th 1989. Dewi was graduated in 2010 from Bogor Agricultural University (IPB), Bogor, West Java, Indonesia majored in Agribusiness. In 2011 Dewi continued her study in master degree Graduate School Bogor Agricultural University majored in Agribusiness Science. She is researcher team and independent staff at Agribusiness Department in 2011. In 2008-2010 she was lecture

assistant of basic economics. She wrote some papers such as Feasibility Analysis Business Development GoatDairy, Livestock Prima Cases Fit, Ciampea district, Bogor, West Java in 2010.

Triana, BA joined some organizations in her college. She joined Students Executive Board Faculty of Economics \& Management FEM IPB (BEM FEM IPB) as Secretary of Economics \& Entrepreneurship Department in 2007-2008. And last, she joined Sharia Economics Student Club as Secretary of Education and Knowledge Division in 2008-2009.

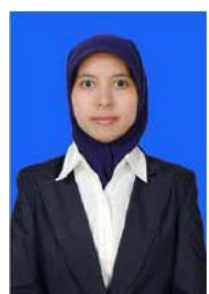

Arini Hardjanto was born in Bogor, West Java, Indonesia on March, 5th 1988. Arini was graduated in 2010 from Bogor Agricultural University (IPB), Bogor, West Java, Indonesia majored in Environmental and Resource Economics . In 2011 Arini continued her study in master degree Graduate School Bogor Agricultural University majored in Agricultural Economy.

She is lecture asisstant of basic economics and benefit cost analysis at Faculty of Economic and Management

IPB in 2011-now. She was junior researcher at Faculty of Economic and Management IPB in 2010-2011. She wrote some papers such as Market Intelligence Strategic Commodity Export in 2010-2011; Economic Estimation And Determinants Of Zakah Potential In Indonesia.

Arini, BA joined some organizations in her college. She joined Students Executive Board Faculty of Economics \& Management FEM IPB (BEM FEM IPB) as staff of Politic and Strategic Development Department in 2007-2008. She joined Resource and Environmental Economics Student Association (REESA) FEM IPB as Head of Entrepreneurship division in 2008-2009. 